\title{
Clinical features and intervention timing in patients with pregnancy-associated non-small-cell lung cancer
}

\author{
Lei Yang ${ }^{1,2 \#}$, Yun-Ting He, ${ }^{1,2 \#}$, Jin Kang ${ }^{2}$, Ming-Ying Zheng ${ }^{2}$, Zhi-Hong Chen ${ }^{2}$, Hong-Hong Yan $^{2}$, \\ Xu-Chao Zhang ${ }^{2}$, Jin-Ji Yang ${ }^{2}$, Yi-Long Wu ${ }^{2}$, Qing Zhou ${ }^{1,2}$
}

${ }^{1}$ The Second School of Clinical Medicine, Southern Medical University, Guangzhou, China; ${ }^{2}$ Guangdong Lung Cancer Institute, Guangdong Provincial People's Hospital, Guangdong Academy of Medical Sciences, Guangzhou, China

Contributions: (I) Conception and design: L Yang, YT He, Q Zhou, YL Wu; (II) Administrative support: Q Zhou, ZH Chen; (III) Provision of study materials or patients: J Kang, MY Zheng, XC Zhang, JJ Yang; (IV) Collection and assembly of data: L Yang, YT He; (V) Data analysis and interpretation: L Yang, YT He, HH Yan, Q Zhou, YL Wu; (VI) Manuscript writing: All authors; (VII) Final approval of manuscript: All authors.

\#These authors contributed equally to this work.

Correspondence to: Qing Zhou, MD, PhD. Guangdong Lung Cancer Institute, Guangdong Provincial People's Hospital, 106 Zhongshan 2nd Road, Guangzhou 510080, China. Email: gzzhouqing@126.com.

\begin{abstract}
Background: There is no standard procedure available to diagnose and treat with pregnancy-associated non-small cell lung cancer (NSCLC). The present study was to investigate the clinical and molecular features, and the proper intervention timing for this population.

Methods: This is a retrospective, pooled analysis. Cases from Guangdong Lung Cancer Institute and other published cases were collected and reviewed. The overall survival (OS) was analyzed according to the diagnosis timing, the treatment timing and the molecular character. The safety profile during pregnancy was also evaluated.

Results: Seventy-seven cases were collected including 11 patients from our center. The anaplastic lymphoma kinase $(A L K)$ gene rearrangement and epidermal growth factor receptor $(E G F R)$ mutation rates were $47 \%$ and $32 \%$, respectively. The OS of patients treated during pregnancy, after delivery, and those not treated differed significantly $[12$ months vs. not reached $(\mathrm{NR})$ vs. 1 month; $\mathrm{P}<0.001]$. However, the OS between patients treated during pregnancy and after delivery was similar $(\mathrm{P}=0.173)$. Patients with $A L K$ or EGFR exhibited a significantly better OS than those with wild-type [NR vs. 22 months vs. 8 months; $\mathrm{P}<0.001$; hazard ratio $(\mathrm{HR})=0.02,95 \%$ confidence interval $(\mathrm{CI}): 0.00-0.22 ; \mathrm{HR}=0.08,95 \%$ CI: 0.01-0.76]. Fetal complications were observed in babies whose mothers were treated during pregnancy.

Conclusions: The pregnancy-associated NSCLC population exhibited a high prevalence of driver genes and a promising effect of targeted therapy. No significant difference in the OS was observed between patients treated during pregnancy and patients treated after delivery.
\end{abstract}

Keywords: Non-small cell lung cancer (NSCLC); pregnancy; survival; molecular pathology; intervention timing

Submitted Feb 24, 2021. Accepted for publication May 27, 2021.

doi: $10.21037 /$ jtd-21-234

View this article at: https://dx.doi.org/10.21037/jtd-21-234

\section{Introduction}

Pregnancy-associated lung cancer is defined as lung cancer diagnosed during pregnancy and within 1 year of delivery (1). Risk of lung cancer during pregnancy increases with the prevalence of smoking in women and late pregnancy among women. The situation of patients with lung cancer associated with pregnancy is complicated. It seriously affects the physical and mental health of the patients, and burdens the society, patients, and families both mentally and economically. More than 70 cases of pregnancy-associated lung cancer have been reported till date, including its 
clinical manifestations, treatments, and outcomes. The median age of these patients is 36 years, and almost $60 \%$ of them were smokers (2).

In the past decade, pathological and molecular features have become crucial in the development of a treatment plan in patients with lung cancer. A single-center study from the United States reported that eight patients were diagnosed with lung adenocarcinoma during pregnancy or in postpartum period. Six of them had anaplastic lymphoma kinase $(A L K)$ gene rearrangement and the other two carried epidermal growth factor receptor (EGFR) mutation (3). The pathological and molecular characteristics of patients with non-small cell lung cancer (NSCLC) associated with pregnancy are still unclear.

A major challenge in cancers in pregnant women is using a standard chemotherapy regimen while simultaneously avoiding risks to the developing fetus. Exposure to chemotherapy in the first trimester is associated with increased risk of major birth defects, and in the second and third trimesters it is associated with intrauterine growth retardation (IUGR), low birthweight, and stillbirth (4). Therefore, it is advised that adverse effects on the fetus as well as benefits of chemotherapy to the mother should be considered before deciding the management of the cancer. Chemotherapy has been the predominant option for patients with advanced lung cancer in the past. However, with the introduction of targeted therapeutics, targeted therapy has already become the first-line treatment for patients with NSCLC with gene mutations such as EGFR or $A L K$. The treatment of pregnancy-associated NSCLC is much more complicated because not much is known about the efficacy and safety of targeted therapy during pregnancy. Additionally, the optimal strategy of proper intervention choice and timing in these patients is uncertain.

Therefore, the present study collected information on relevant cases to study the clinical and molecular features, and to explore the timing of diagnosis and appropriate interventions in pregnant women with NSCLC.

We present the following article in accordance with the STROBE reporting checklist (available at https://dx.doi. org/10.21037/jtd-21-234).

\section{Methods}

\section{Participants and data collection}

The present study was conducted in patients between 18 and 50 years of age who had been pathologically diagnosed with lung cancer at the Guangdong Lung Cancer Institute from January 2008 to December 2019. Patients diagnosed with NSCLC during pregnancy or within 1 year of delivery were included in the study. The demographic characteristics, clinical and molecular features, intervention, and follow-up data of the included patients were extracted from electronic medical record. The survival outcome was assessed through follow-up by phone. The cutoff date was April 2020. The overall survival (OS) was defined as the time from diagnosis to death.

A systematic search using search strategies comprising the keywords "lung neoplasms/lung cancer" and "pregnancy/gestation" was performed in the Medline, CNKI, and Wanfang databases. Searches were limited to human studies published in English and Chinese languages. The final search was performed in March 2020. After duplicates were removed, the remaining titles and abstracts were manually screened. Full texts of relevant articles were retrieved. Review articles, case series without primary data, and articles on patients diagnosed with small cell lung cancer were excluded from the search results. Figure 1 is a flowchart to show the screening process of cases included in the present study. Patient demographics, diagnosis, treatment, and outcome data were collected from case reports. Most of the patients were staged by the 7th edition of TNM Staging Criteria (UICC).

\section{Grouping}

Patients with follow-up data were enrolled in survival analysis. Patients with a precise time of diagnosis were divided into the following three groups: (I) the first trimester of gestation: $0-11^{+6}$ weeks; (II) the second trimester of gestation: $12-27^{+6}$ weeks; (III) the third trimester of gestation or after delivery: more than 28 weeks. According to the initiation time of anticancer treatment, patients were divided into the following two groups: (I) during pregnancy; (II) after delivery. Patients with molecular pathology information were divided into the following three groups: (I) $A L K$ rearrangement; (II) $E G F R$ mutation; (III) wild-type.

\section{Statistical analysis}

Statistical analysis was performed using GraphPad Prism 7.0 and SPSS 20.0. Clinicopathological characteristics and patient outcomes were summarized descriptively. The Kaplan-Meier method was used to construct survival curves and calculate median OS. Cox regression analysis was used to derive hazard ratios (HRs) and $95 \%$ confidence intervals 


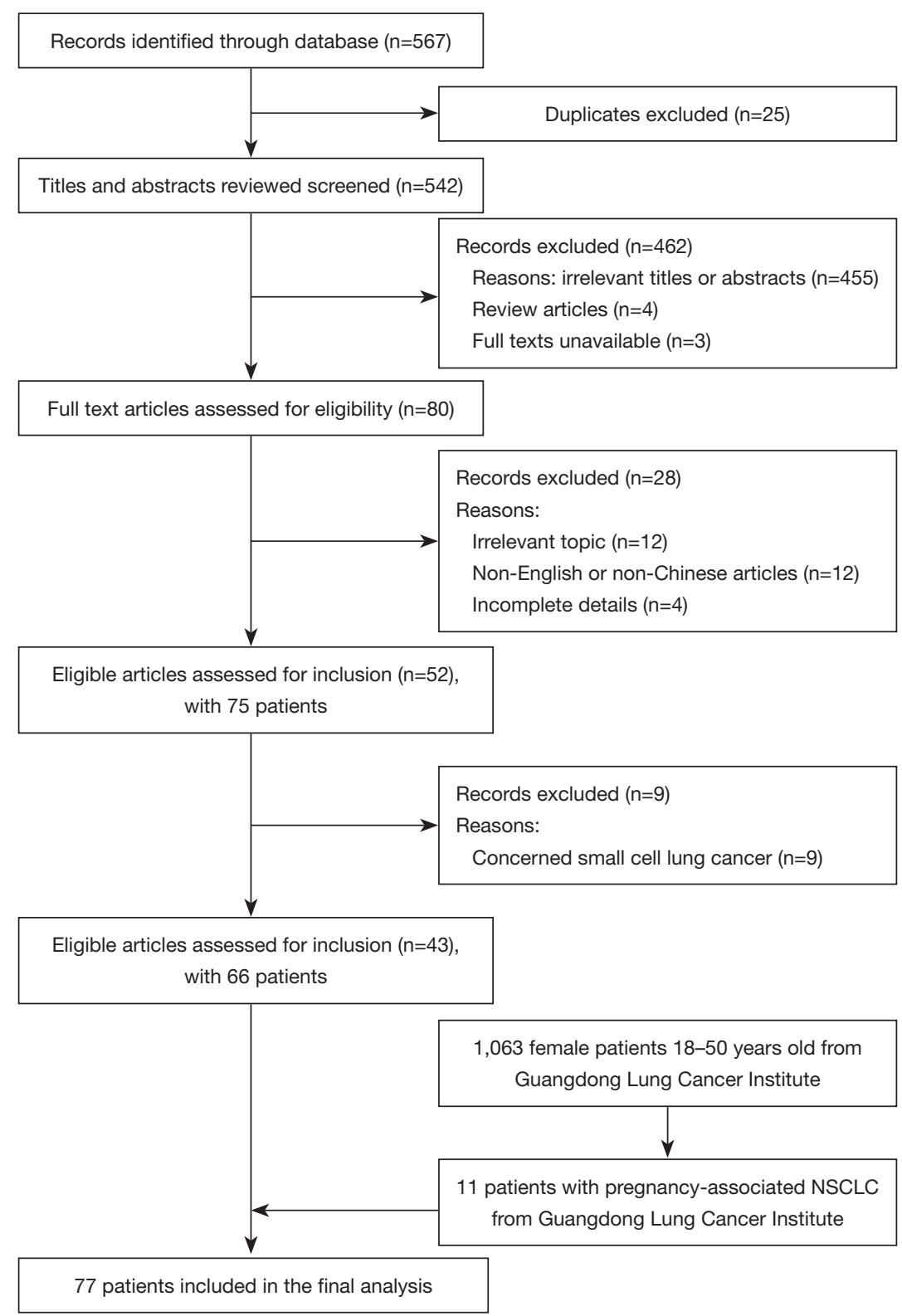

Figure 1 Diagram describing the cases selection.

(CIs). The safety profile during pregnancy was reviewed. Chi-square test was launched to compare the frequency of fetal complications between patients treated and untreated during pregnancy. A P value $\leq 0.05$ was considered statistically significant.

\section{Ethical statement}

The study was conducted in accordance with the Declaration of Helsinki (as revised in 2013). The study was approved by institutional ethics board of Guangdong Provincial People's Hospital [No. GDREC2019304H(R1)] and individual consent for this retrospective analysis was waived.

\section{Results}

\section{Summaries of the cases in Guangdong Lung Cancer Institute}

Eleven cases of pregnancy-associated NSCLC were 
identified among 1,063 female patients in Guangdong Lung Cancer Institute (Table 1). The median age of 31 years, and none of the patients were smokers. The frequent presenting symptoms were cough, dyspnea, and chest/back pain. Three patients were diagnosed during pregnancy and eight patients were diagnosed after delivery. Of the 11 patients, four delivered living babies, four received induced abortions, one had a spontaneous abortion, one patient died with a stillbirth and one patient with unknown fetal outcome. The timing of delivery and fetal complications were unknown. The majority of patients had NSCLC stage IV, whereas one with stage I and another with unknown stage. Adenocarcinoma was observed in eight cases, whereas lymphoepithelioma-like carcinoma was observed in three cases. Of the ten patients who underwent gene testing, one had EGFR 19del, four had $A L K$ rearrangements, and five were wild-type cases of NSCLC. None of the patients received anticancer therapy during pregnancy. Two patients received surgery after delivery. The only patient with EGFR 19del received icotinib as first-line treatment, and had an OS of 17 months. Three of four patients with $A L K$ rearrangements received targeted therapies, and were still alive at the time of last visit when followed up for 21, 36, and 38 months. Most of the patients without driver genes received chemotherapy.

\section{Total cases of gestational lung cancers in literature}

A total of 77 cases were collected for analysis in the present study, including 11 from the Guangdong Lung Cancer Institute (Table 2). The median age of the patients was 34 years. Approximately $20 \%$ of patients had a history of smoking. The common symptoms were cough, dyspnea, and chest/back pain. The time interval from the onset of symptoms to admission to the hospital was approximately 2 months. Fifty-five patients were diagnosed during pregnancy and 16 patients were diagnosed after delivery. Almost half of the patients gave birth to healthy babies, approximately $20 \%$ of patients received induced abortion, and placental metastasis occurred in four. The majority of tumors were at an advanced stage at the time of diagnosis with pathological types such as adenocarcinoma and squamous cell carcinoma. Genetic analysis was conducted in 34 patients before treatment. Of these, EGFR mutations were detected in $11(32 \%)$ patients, $A L K$ rearrangements occurred in $16(47 \%)$ patients, and the remaining seven patients had the wild-type allele. No other driver-gene mutations were found. During pregnancy, 24 patients received anticancer therapies and 48 patients did not. After delivery, 54 patients received anticancer therapies and 16 patients did not. Approximately half of patients received chemotherapy and targeted therapy; 11 patients received surgery and 22 patients received radiotherapy, whereas one patient received immunotherapy.

\section{Survival outcomes}

The final survival analysis was conducted in 64 patients with follow-up information. The median OS was 16 months. The 3-month, 6-month, 1-year, and 2-year survival rates were $76.3 \%, 69.7 \%, 52.5 \%$, and $34.8 \%$, respectively. The OS of patients diagnosed in the first $(n=7)$, second $(n=26)$, and third trimester $(\mathrm{n}=28)$ of pregnancy or after delivery exhibited no significant difference [not reached (NR) vs. 10 months vs. 16 months; $\mathrm{P}=0.347]$. Anticancer therapy was administered to 19 patients during pregnancy and 33 after delivery, whereas 6 patients did not receive any anticancer treatment. The OS of patients treated during pregnancy, after delivery and without treatment was 12 months, NR and 1 month respectively $(\mathrm{P}<0.001)$. The OS of patients treated during pregnancy and after delivery was similar (12 months vs. NR; $\mathrm{P}=0.173 ; \mathrm{HR}=1.75,95 \%$ CI: $0.74-4.13$ ) (Figure 2). Patients with $A L K(\mathrm{n}=13)$ and EGFR $(\mathrm{n}=10)$ mutations exhibited significantly better OS than those with the wild-type ( $\mathrm{n}=7$ ) (NR vs. 22 months vs. 8 months; $\mathrm{P}<0.001 ; \mathrm{HR}=0.02$, 95\% CI: $0.00-0.22 ; \mathrm{HR}=0.08,95 \%$ CI: 0.01-0.76) (Figure 3).

\section{Adverse effects in patients treated during pregnancy}

Fetal adverse effects were observed in babies whose mothers received anticancer therapies during pregnancy (Table 3) (3,5-23). The frequency was about $38 \%$. Platinumdoublet chemotherapy represented the most frequently adopted regimen during pregnancy. Adverse effects such as low weight, oligohydramnios, respiratory distress, and anemia were observed in babies whose mother received chemotherapy. Fetal growth restriction was observed in the two babies whose mother received erlotinib during pregnancy. No adverse event was observed in the two babies whose mother received gefinitib. The frequency of fetal adverse events in babies whose mothers did not receive antineoplastic treatment during pregnancy was $52 \%$. No significant difference was observed in the frequency of fetal complication between patients treated and untreated during pregnancy ( $38 \%$ vs. $52 \%, \mathrm{P}=0.346)$. The overall frequency 


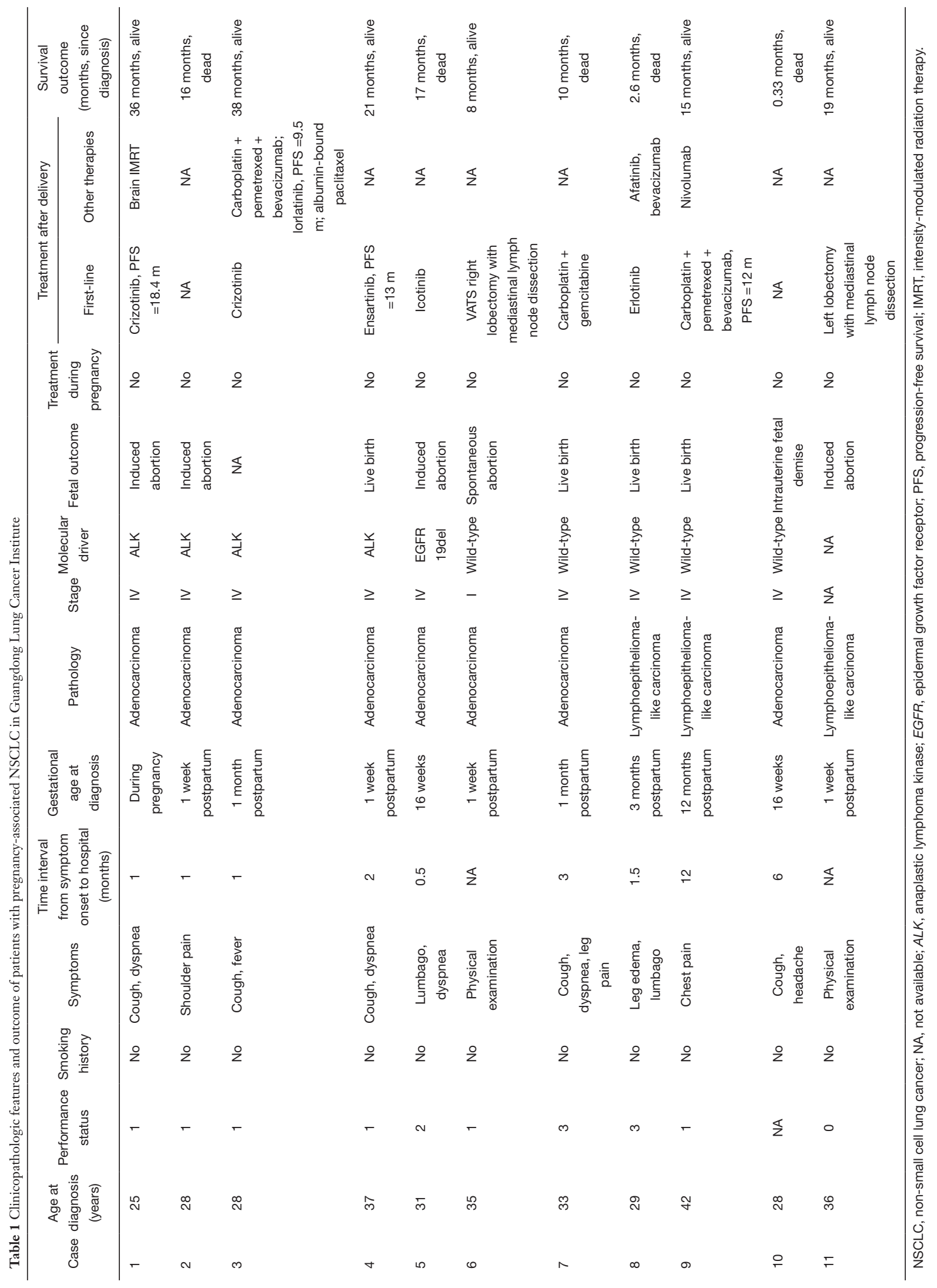


Table 2 Characteristic and outcome of 77 patients with NSCLC associated with pregnancy

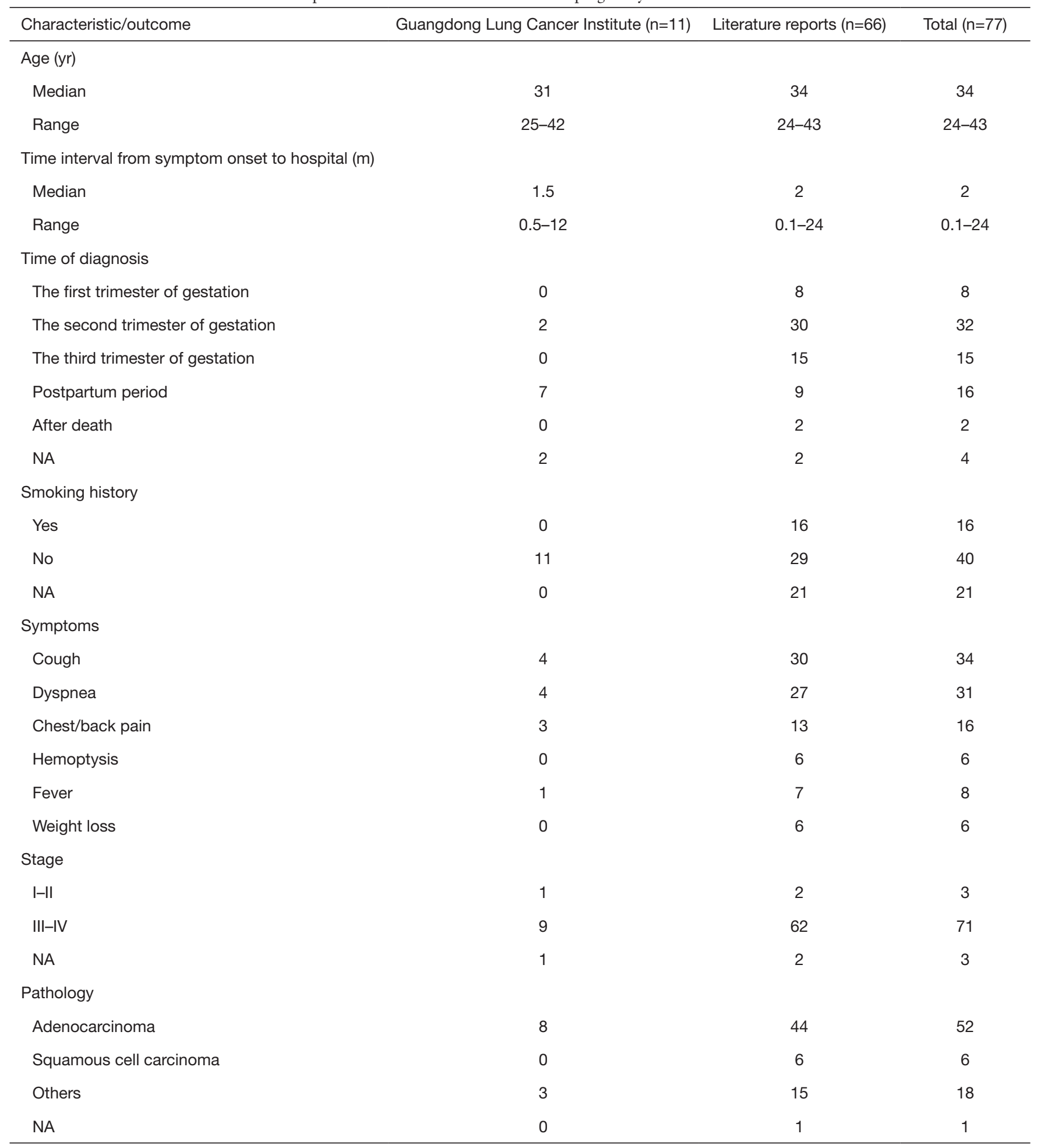

Table 2 (continued) 
Table 2 (continued)

\begin{tabular}{|c|c|c|c|}
\hline Characteristic/outcome & Guangdong Lung Cancer Institute $(n=11)$ & Literature reports $(n=66)$ & Total $(n=77)$ \\
\hline \multicolumn{4}{|l|}{ Genotype } \\
\hline EGFR & 1 & 10 & 11 \\
\hline$A L K$ & 4 & 12 & 16 \\
\hline Wild-type & 5 & 2 & 7 \\
\hline NA & 1 & 42 & 43 \\
\hline \multicolumn{4}{|l|}{ Fetal outcome } \\
\hline Normal & 0 & 30 & 30 \\
\hline Induced abortion & 4 & 11 & 15 \\
\hline Spontaneous abortion & 1 & 1 & 2 \\
\hline NA & 6 & 20 & 26 \\
\hline \multicolumn{4}{|c|}{ Treatment during pregnancy } \\
\hline Yes & 0 & 24 & 24 \\
\hline No & 10 & 38 & 48 \\
\hline NA & 1 & 3 & 4 \\
\hline \multicolumn{4}{|l|}{ Treatment after delivery } \\
\hline Yes & 9 & 45 & 54 \\
\hline No & 0 & 16 & 16 \\
\hline NA & 2 & 5 & 7 \\
\hline \multicolumn{4}{|l|}{ Therapy methods } \\
\hline Surgery & 2 & 9 & 11 \\
\hline Chemotherapy & 3 & 30 & 33 \\
\hline Radiotherapy & 0 & 22 & 22 \\
\hline Targeted therapy & 5 & 25 & 30 \\
\hline Immunotherapy & 1 & 0 & 1 \\
\hline
\end{tabular}

NSCLC, non-small cell lung cancer; NA, not available; EGFR, epidermal growth factor receptor; ALK, anaplastic lymphoma kinase.

of fetal adverse effects in babies whose mothers received antineoplastic treatment was $50 \%$.

\section{Discussion}

Patients with pregnancy-associated lung cancer comprise a special population as clinicians are unfamiliar with their clinical characteristics. No standard procedure is available for the diagnosis and treatment of these patients. The present study attempted to investigate the clinical and molecular features, and the treatment options in this population. To the best of our knowledge, this is the largest study addressing this topic to date. The study exhibited the unique clinicopathological characteristics of patients with pregnancy-associated NSCLC. The time of diagnosis was not related with the OS. No significant difference in the OS was observed between patients treated during pregnancy and patients treated after delivery. Genotype was associated with OS.

Shah et al. has reported activating EGFR mutations in approximately $10-15 \%$ of cases with adenocarcinoma in Caucasian patients and $50 \%$ of cases in Asian patients with NSCLC (24). ALK gene rearrangements were observed in $5-7 \%$ of patients with advanced non-squamous 


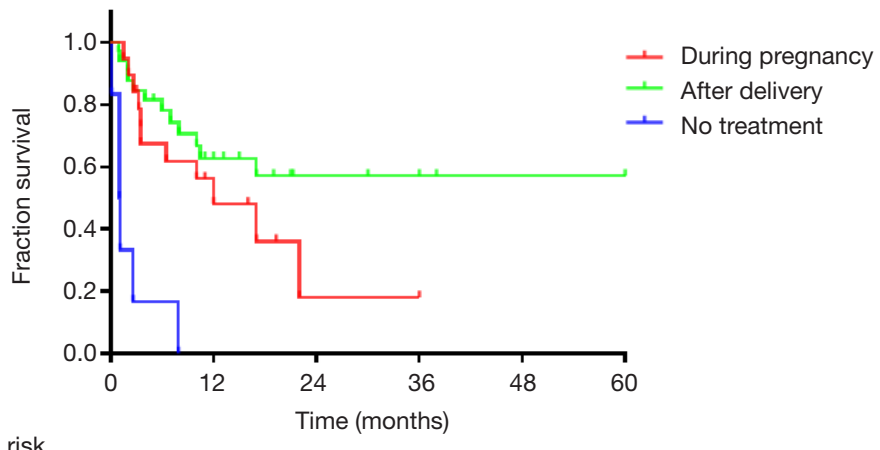

Number at risk

\begin{tabular}{|c|c|c|c|c|}
\hline During pregnancy 19 & 7 & 1 & 1 & 0 \\
\hline After delivery 33 & 24 & 15 & 5 & 3 \\
\hline No treatment 6 & 0 & 0 & 0 & 0 \\
\hline
\end{tabular}

\begin{tabular}{|l|c|c|c|}
\hline \multicolumn{1}{|c|}{ Treatment } & N & OS $(\mathrm{m})$ & P value \\
\hline During pregnancy & 19 & 12 & $<0.001$ \\
\hline After delivery & 33 & NR & \\
\hline No treatment & 6 & 1 & \\
\hline
\end{tabular}

\begin{tabular}{|l|c|c|c|c|c|}
\hline \multicolumn{1}{|c|}{ Treatment } & $\mathrm{N}$ & $\mathrm{OS}(\mathrm{m})$ & $\mathrm{P}$ value & $\mathrm{HR}$ & $95 \% \mathrm{Cl}$ \\
\hline During pregnancy & 19 & 12 & 0.173 & 1.75 & $0.74-4.13$ \\
\hline After delivery & 33 & $\mathrm{NR}$ & & 1.00 & \\
\hline
\end{tabular}

Figure 2 OS of patients initiated anticancer treatment during pregnancy, after delivery, no treatment. (I) Treated during pregnancy $v s$. treated after delivery $v s$. no treatment $(12$ months $v s$. NR vs. 1 months; $\mathrm{P}<0.001)$. (II) Treated during pregnancy $v s$. treated after delivery (12 months vs. NR; $\mathrm{P}=0.173$; HR =1.75, 95\% CI: 0.74 to 4.13). OS, overall survival; NR, not reached; HR, hazard ratio; CI, confidence interval.

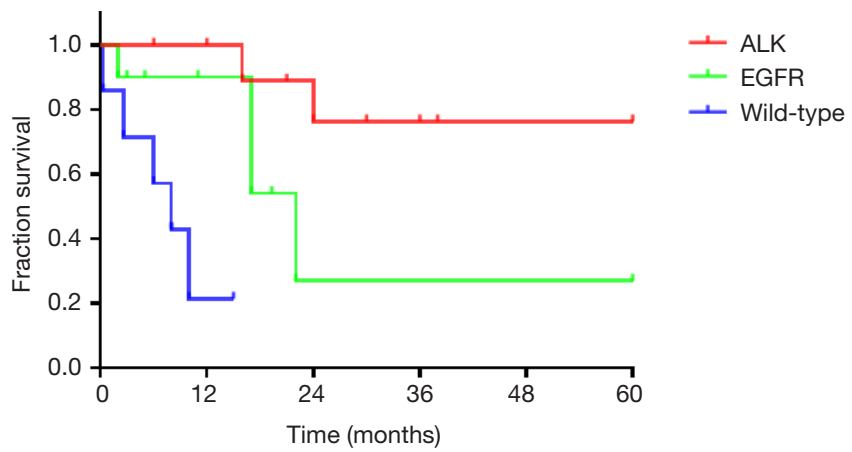

Number at risk

\begin{tabular}{|c|c|c|c|c|}
\hline ALK 13 & 11 & 7 & 4 & 1 \\
\hline EGFR 10 & 5 & 1 & 1 & 1 \\
\hline wild-type 7 & 1 & 0 & 0 & 0 \\
\hline
\end{tabular}

\begin{tabular}{|c|c|c|c|c|c|}
\hline Genotyping & $\mathrm{N}$ & $\mathrm{OS}(\mathrm{m})$ & $\mathrm{P}$ value & $\mathrm{HR}$ & $95 \% \mathrm{Cl}$ \\
\hline ALK & 13 & $\mathrm{NR}$ & $<0.001$ & 0.02 & $0.00-0.22$ \\
\hline EGFR & 10 & 22 & & 0.08 & $0.01-0.76$ \\
\hline wild-type & 7 & 8 & & 1.00 & \\
\hline
\end{tabular}

Figure 3 OS of patients with EGFR mutation, $A L K$ mutation and wild-type. OS, overall survival; $E G F R$, epidermal growth factor receptor; $A L K$, anaplastic lymphoma kinase; NR, not reached; HR, hazard ratio; CI, confidence interval. 
Table 3 Adverse effects of fetus in patients treated during pregnancy

\begin{tabular}{|c|c|c|c|c|c|c|c|c|c|}
\hline Reference & Age & Pathology & Stage & Genotype & $\begin{array}{c}\text { Gestational } \\
\text { age at } \\
\text { diagnosis } \\
\text { (wk) }\end{array}$ & $\begin{array}{l}\text { Treatment during } \\
\text { pregnancy }\end{array}$ & $\begin{array}{l}\text { Timing of } \\
\text { delivery } \\
\text { (wk) }\end{array}$ & Fetal outcome & $\begin{array}{c}\text { Maternal } \\
\text { outcome } \\
\text { (months, since } \\
\text { diagnosis) }\end{array}$ \\
\hline Boussios et al. (5) & 35 & Adenocarcinoma & UK & UK & 6 & Cisplatin + vinorelbine & 33 & UK & 6.50, dead \\
\hline Garrido et al. (6) & 34 & Adenocarcinoma & III & UK & 27 & Cisplatin + vinorelbine & 39 & Normal & 16.00 , alive \\
\hline Jänne et al. (7) & 31 & Adenocarcinoma & IV & UK & 26 & Cisplatin + vinorelbine & 26 & Normal & UK \\
\hline Boussios et al. (5) & 31 & Adenocarcinoma & IV & UK & 20 & Cisplatin + vinorelbine & 26 & $\begin{array}{l}\text { Respiratory distress, } \\
\text { necrotizing enteritis }\end{array}$ & 2.07 , dead \\
\hline $\begin{array}{l}\text { García-González } \\
\text { et al. (8) }\end{array}$ & 39 & Adenocarcinoma & III-IV & UK & 17 & Cisplatin + paclitaxel & 30 & Respiratory distress & 10.00, dead \\
\hline Iliaz et al. (9) & 28 & Adenocarcinoma & IV & UK & 22 & Cisplatin & 32 & Normal & UK \\
\hline Kim et al. (10) & 35 & Adenocarcinoma & IV & UK & 31 & Cisplatin + docetaxel & 33 & Normal & 10.00, alive \\
\hline Dagogo-Jack et al. (3) & 29 & Adenocarcinoma & IV & ALK & 9 & $\begin{array}{l}\text { Carboplatin + paclitaxel, } \\
\text { gamma knife radiosurgery }\end{array}$ & 34 & Normal & 36.00 , alive \\
\hline Boussios et al. (5) & 42 & Adenocarcinoma & IV & UK & 13 & Carboplatin + paclitaxel & 27 & Normal & 3.53 , dead \\
\hline Azim et al. (11) & 33 & Adenocarcinoma & IV & UK & 19 & Carboplatin + paclitaxel & 30 & Normal & 3.50 , dead \\
\hline Holzmann et al. (12) & 29 & Adenocarcinoma & IV & EGFR 19del & 26 & $\begin{array}{l}\text { Carboplatin + docetaxel, } \\
\text { palliative radiotherapy for } \\
\text { the thoracic spine }\end{array}$ & 31 & Normal & 17.00, dead \\
\hline Gil et al. (13) & 33 & Adenocarcinoma & IV & EGFR 19del & 26 & $\begin{array}{l}\text { Gefitinib, stereotactic } \\
\text { radiotherapy for brain }\end{array}$ & 35 & Normal & 22.00, dead \\
\hline Lee et al. (14) & 38 & Adenocarcinoma & IV & EGFR 19del & 26 & Gefitinib & 36 & Normal & 3.00, alive \\
\hline Ji et al. (15) & 40 & Adenocarcinoma & IV & EGFR 19del & 10 & $\begin{array}{l}\text { Erlotinib, radiotherapy for } \\
\text { brain }\end{array}$ & 37 & $\begin{array}{l}\text { Intrauterine growth } \\
\text { restriction }\end{array}$ & 19.30, alive \\
\hline Rivas et al. (16) & 40 & Adenocarcinoma & IV & $\begin{array}{c}\text { EGFR } \\
21 \mathrm{~L} 858 \mathrm{R}\end{array}$ & 3 & Erlotinib & 33 & $\begin{array}{l}\text { Intrauterine } \\
\text { growth restriction, } \\
\text { oligohydramnios }\end{array}$ & 11.00, alive \\
\hline Padrão et al. (17) & 36 & Adenocarcinoma & IV & ALK & 22 & Crizotinib & 30 & Placental metastasis & UK \\
\hline Mujaibel et al. (18) & 35 & Adenocarcinoma & IV & UK & 31 & Whole-brain radiotherapy & 34 & Normal & 2.70, dead \\
\hline Magné et al. (19) & 38 & Adenocarcinoma & IV & UK & 24 & $\begin{array}{l}\text { Intracranial tumor } \\
\text { resection, whole-brain } \\
\text { radiotherapy }\end{array}$ & UK & Normal & 58.00 , alive \\
\hline Wang et al. (20) & 27 & $\begin{array}{l}\text { Squamous cell } \\
\text { carcinoma }\end{array}$ & IV & UK & 1 & Cisplatin + vinorelbine & 37 & Low birth weight & 9.00 , dead \\
\hline Yates et al. (21) & 26 & $\begin{array}{l}\text { Lymphoepithelioma- } \\
\text { like carcinoma }\end{array}$ & III & UK & 18 & Cisplatin + docetaxel & 35 & Normal & 16.00, alive \\
\hline Kim et al. (22) & 38 & Large cell carcinoma & $\|$ & UK & 24 & $\begin{array}{l}\text { VATS right lobectomy with } \\
\text { mediastinal lymph node } \\
\text { dissection }\end{array}$ & 37 & Normal & 10.00, alive \\
\hline Boussios et al. (5) & 32 & large cell carcinoma & IV & UK & 19 & Cisplatin + etoposide & 33 & Normal & 3.27 , dead \\
\hline Gurumurthy et al. (23) & 38 & $\begin{array}{l}\text { Poorly differentiated } \\
\text { carcinoma }\end{array}$ & IV & UK & 24 & Carboplatin + gemcitabine & $28^{+4}$ & $\begin{array}{c}\text { Anemia, chronic lung } \\
\text { diseases }\end{array}$ & 1.53, dead \\
\hline Boussios et al. (5) & 26 & $\begin{array}{l}\text { Poorly differentiated } \\
\text { carcinoma }\end{array}$ & IV & UK & 17 & $\begin{array}{l}\text { Cisplatin + vinorelbine, } \\
\text { gamma knife radiosurgery }\end{array}$ & 23 & Oligohydramnios & 12.00, dead \\
\hline
\end{tabular}

$A L K$, anaplastic lymphoma kinase; EGFR, epidermal growth factor receptor. 
NSCLC (25). Our study estimated that the EGFR mutation rate was $32 \%$, whereas the $A L K$ rearrangement rate was $47 \%$, which was much higher than the rate of general lung cancer patients. This disparity may be due to a lower smoking rate and younger age in this population. There are no reports on the relationship between driver genes and pregnancy. A single-center study from the United States reported that EGFR mutations were detected in approximately $25 \%$ of patients with pregnancy-associated NSCLC (3). However, only one patient was detected with EGFR 19del in the Guangdong Lung Cancer Institute. The rate of patients with $A L K$ rearrangements in the Guangdong Lung Cancer Institute was as high as $40 \%$. This finding was consistent with a previous report by Dagogo-Jack et al. (3).

Chest pain, cough, and dyspnea are non-specific symptoms of lung diseases. Imaging procedures are limited due to concerns of radiation exposure damage to the fetus. Furthermore, these cases are so uncommon that some doctors misdiagnose them as pneumonia, asthma, tuberculosis, and eclampsia, often delaying the diagnosis of lung cancer in pregnant women $(18,22,26,27)$. Our study demonstrated that the difference in the OS of patients diagnosed in the first, second, or third trimester of gestation, or after delivery was not statistically significant. Radical examinations such as computed tomography, and bone and positron emission tomography scans may not be necessary in pregnant women with mild symptoms as these may produce greater fetal damage. According to the guidelines (28), chest X-ray can be safely performed with abdominal shielding during pregnancy, whereas magnetic resonance imaging without gadolinium and ultrasound can also be used.

Our study exhibited that there was no significant difference in OS between patients treated during pregnancy and patients treated after delivery. In some urgent cases, anticancer therapy during pregnancy relieved the symptoms rapidly, which bought time and prepared better conditions for subsequent treatment. However, anticancer therapy during pregnancy might cause simultaneous fetal adverse events. Thus, the initiation of anticancer treatments in pregnant patients is complicated. Chemotherapy may produce teratogenic effects in the fetus. The risk of fetal congenital malformations reached as high as $20 \%$ in the first trimester of gestation when chemotherapeutic agents were used. The preferred chemotherapeutic agents are carboplatin combined with weekly paclitaxel, whereas antimetabolites such as gemcitabine and pemetrexed must be avoided. EGFR inhibitors are not recommended during pregnancy. Jovelet et al. reported that EGFR-tyrosine kinase inhibitors (TKIs) crossed the placenta at a therapeutic level, with a simultaneous low placental uptake (29). Erlotinib crossed the placenta at a higher rate than gefitinib, which might explain why fetal growth restriction was observed in the two patients treated with erlotinib in our study $(15,16,29)$. On the contrary, crizotinib crossed the placental barrier only to a small extent but strongly accumulated in placental tissue, which could impair trophoblast cell viability and placental barrier function (30). The concentration of crizotinib in umbilical cord blood was shown to be extremely low in a case report (31). Use of targeted therapy during pregnancy should still be considered carefully because of the lack of data. Some patients did not receive any anticancer therapies due to poor general condition and rapid progression of lung cancer (32-34). The prognosis of such patients was poor. Fetal adverse events were also reported in patients without anticancer therapy during pregnancy. And the frequency of fetal complication was similar in patients treated and untreated during pregnancy. We do not know whether the observed fetal adverse events were related to the anticancer treatment.

An increasing number of patients are undergoing genetic analysis and receiving genotype-directed therapy in recent years. Lung cancer in young female non-smokers is often driven by oncogenic mutations. Our study demonstrated that the OS of patients with driver genes was better than the wild-type. The median OS was 22 months in patients with EGFR mutations, near to the 22.8-34.8 months reported in literature $(24,35,36)$. The median OS in patients with $A L K$ rearrangement in our study was NR, but reports state that the OS might be remarkably long, up to 7 years (25). Therefore, molecular genotyping examination in nonsmokers with pregnancy-associated lung cancer is essential because the efficacy of targeted therapy in this special population was as good as the general patients.

The present study has certain limitations. All cases were evaluated retrospectively, resulting in a considerable proportion of missing data. The sample size of study was small and the baseline characteristics were unbalanced across the groups. Most of cases were obtained from literature and the conclusions depended on the reliability of case reports. Therefore, the conclusions should be interpreted carefully.

In conclusion, patients with pregnancy-associated NSCLC constitute a special complicated population with unique clinicopathological characteristics. The particular population should receive gene test and get 
the opportunities of target therapy because of the high incidence of driver gene mutation and the promising efficacy.

\section{Acknowledgments}

Funding: This work was supported by the National Key R\&D Program of China (No. 2016YFC1303800 to QZ), High-Level Hospital Construction Project (No. DFJH201810 to QZ), GDPH Scientific Research Funds for Leading Medical Talents and Distinguished Young Scholars in Guangdong Province (No. KJ012019428 to QZ), and Key Lab System Project of Guangdong Science and Technology Department - Guangdong Provincial Key Lab of Translational Medicine in Lung Cancer (No. 2017B030314120 to YLW).

\section{Footnote}

Reporting Checklist: The authors have completed the STROBE reporting checklist. Available at https://dx.doi. org/10.21037/jtd-21-234

Data Sharing Statement: Available at https://dx.doi. org/10.21037/jtd-21-234

Peer Review File: Available at https://dx.doi.org/10.21037/ jtd-21-234

Conflicts of Interest: All authors have completed the ICMJE uniform disclosure form (available at https://dx.doi. org/10.21037/jtd-21-234). QZ declares speaker fees from AstraZeneca, and Roche. YLW declares speaker fees from AstraZeneca, Eli Lilly, Pfizer, Roche, and Sanofi. The other authors have no conflicts of interest to declare.

Ethical Statement: The authors are accountable for all aspects of the work in ensuring that questions related to the accuracy or integrity of any part of the work are appropriately investigated and resolved. The study was conducted in accordance with the Declaration of Helsinki (as revised in 2013). The study was approved by institutional ethics board of Guangdong Provincial People's Hospital [No. GDREC2019304H(R1)] and individual consent for this retrospective analysis was waived.

Open Access Statement: This is an Open Access article distributed in accordance with the Creative Commons
Attribution-NonCommercial-NoDerivs 4.0 International License (CC BY-NC-ND 4.0), which permits the noncommercial replication and distribution of the article with the strict proviso that no changes or edits are made and the original work is properly cited (including links to both the formal publication through the relevant DOI and the license). See: https://creativecommons.org/licenses/by-nc-nd/4.0/.

\section{References}

1. Zagouri F, Dimitrakakis C, Marinopoulos S, et al. Cancer in pregnancy: disentangling treatment modalities. ESMO Open 2016;1:e000016.

2. Pavlidis N. Lung cancer during pregnancy: an emerging issue. Lung Cancer 2008;59:279-81.

3. Dagogo-Jack I, Gainor J, Porter R, et al. Clinicopathologic features of NSCLC diagnosed during pregnancy or the peripartum period in the era of molecular genotyping. J Thorac Oncol 2016;11:1522-8.

4. Ngu SF, Ngan HY. Chemotherapy in pregnancy. Best Pract Res Clin Obstet Gynaecol 2016;33:86-101.

5. Boussios S, Han S, Fruscio R, et al. Lung cancer in pregnancy: report of nine cases from an international collaborative study. Lung Cancer 2013;82:499-505.

6. Garrido M, Clavero J, Huete A, et al. Prolonged survival of a woman with lung cancer diagnosed and treated with chemotherapy during pregnancy. Review of cases reported. Lung Cancer 2008;60:285-90.

7. Jänne PA, Rodriguez-Thompson D, Metcalf DR, et al. Chemotherapy for a patient with advanced non-small-cell lung cancer during pregnancy: a case report and a review of chemotherapy treatment during pregnancy. Oncology 2001;61:175-83.

8. García-González J, Cueva J, Lamas M, et al. Paclitaxel and cisplatin in the treatment of metastatic non-small-cell lung cancer during pregnancy. Clin Transl Oncol 2008;10:375-6.

9. Iliaz S, Iliaz R, Avsar N, et al. Lung cancer presenting with choroidal metastasis in a pregnant woman. Indian J Chest Dis Allied Sci 2014;56:249-51.

10. Kim JH, Kim HS, Sung CW, et al. Docetaxel, gemcitabine, and cisplatin administered for non-small cell lung cancer during the first and second trimester of an unrecognized pregnancy. Lung Cancer 2008;59:270-3.

11. Azim HA Jr, Scarfone G, Peccatori FA. Carboplatin and weekly paclitaxel for the treatment of advanced non-small cell lung cancer (NSCLC) during pregnancy. J Thorac Oncol 2009;4:559-60.

12. Holzmann K, Kropfmüller R, Schinko H, et al. 
Lung cancer in pregnancy. Wien Klin Wochenschr 2015;127:639-44.

13. Gil S, Goetgheluck J, Paci A, et al. Efficacy and safety of gefitinib during pregnancy: case report and literature review. Lung Cancer 2014;85:481-4.

14. Lee CH, Liam CK, Pang YK, et al. Successful pregnancy with epidermal growth factor receptor tyrosine kinase inhibitor treatment of metastatic lung adenocarcinoma presenting with respiratory failure. Lung Cancer 2011;74:349-51.

15. Ji Y, Schwartz J, Hartford A, et al. Successful treatment of non-small cell lung cancer with erlotinib throughout pregnancy. JAMA Oncol 2015;1:838-40.

16. Rivas G, Llinás N, Bonilla C, et al. Use of erlotinib throughout pregnancy: a case-report of a patient with metastatic lung adenocarcinoma. Lung Cancer 2012;77:469-72.

17. Padrão E, Melo C, Fernandes G, et al. Lung cancer in pregnancy - Report of a case treated with crizotinib. Pulmonology 2018;24:205-7.

18. Mujaibel K, Benjamin A, Delisle M, et al. Lung cancer in pregnancy: case reports and review of the literature. J Matern Fetal Med 2001;10:426-32.

19. Magné N, Marcié S, Pignol JP, et al. Radiotherapy for a solitary brain metastasis during pregnancy: a method for reducing fetal dose. Br J Radiol 2001;74:638-41.

20. Wang S, Huo S, Sun G. A case of lung cancer complicated with pregnancy and literature review. J Clinic Pulm Med 2011;16:1820-1.

21. Yates R, Zhang J. Lung cancer in pregnancy: an unusual case of complete response to chemotherapy. Cureus 2015;7:e440.

22. Kim JW, Kim JS, Cho JY, et al. Successful video-assisted thoracoscopic lobectomy in a pregnant woman with lung cancer. Lung Cancer 2014;85:331-4.

23. Gurumurthy M, Koh P, Singh R, et al. Metastatic nonsmall-cell lung cancer and the use of gemcitabine during pregnancy. J Perinatol 2009;29:63-5.

24. Shah R, Lester J. Tyrosine kinase inhibitors for the treatment of EGFR mutation-positive non-small-cell lung cancer: a clash of the generations. Clin Lung Cancer 2020;21:e216-28.

25. Remon J, Ahn M, Girard N, et al. Advanced-stage nonsmall cell lung cancer: advances in thoracic oncology 2018. J Thorac Oncol 2019;14:1134-55.
26. Shah R, Vaideeswar P, Cochin T. Gestational pulmonary giant cell carcinoma - An autopsy report. Indian J Cancer 2020;57:102-4.

27. Sarıman N, Levent E, Yener N, et al. Lung cancer and pregnancy. Lung Cancer 2013;79:321-3.

28. Tirada N, Dreizin D, Khati N, et al. Imaging pregnant and lactating patients. Radiographics 2015;35:1751-65.

29. Jovelet C, Seck A, Mir O, et al. Variation in transplacental transfer of tyrosine kinase inhibitors in the human perfused cotyledon model. Ann Oncol 2015;26:1500-4.

30. Eliesen GAM, van den Broek P, van den Heuvel JJ, et al. Editor's Highlight: PlacentalDisposition and effects of crizotinib: an ex vivo study in the isolated dual-side perfused human cotyledon. Toxicol Sci 2017;157:500-9.

31. Jensen KH, Persson G, Storgaard L, et al. Antineoplastic treatment with crizotinib during pregnancy: a case report. Acta Oncol 2019;58:121-2.

32. Ceau u M, Hostiuc S, Sajin M, et al. Gestational lung adenocarcinoma: case report. Int J Surg Pathol 2014;22:663-6.

33. Jackisch C, Louwen F, Schwenkhagen A, et al. Lung cancer during pregnancy involving the products of conception and a review of the literature. Arch Gynecol Obstet 2003;268:69-77.

34. Jiménez-Zarazúa O, Vélez-Ramírez L, Padilla-López J, et al. Invasive pulmonary adenocarcinoma with lepidic growth pattern in a pregnant patient. Case Rep Oncol 2018;11:822-34.

35. Inoue A, Kobayashi K, Maemondo M, et al. Updated overall survival results from a randomized phase III trial comparing gefitinib with carboplatin-paclitaxel for chemonaïve non-small cell lung cancer with sensitive EGFR gene mutations (NEJ002). Ann Oncol 2013;24:54-9.

36. Zhou C, Wu Y, Chen G, et al. Final overall survival results from a randomised, phase III study of erlotinib versus chemotherapy as first-line treatment of EGFR mutationpositive advanced non-small-cell lung cancer (OPTIMAL, CTONG-0802). Ann Oncol 2015;26:1877-83.

Cite this article as: Yang L, He YT, Kang J, Zheng MY, Chen ZH, Yan HH, Zhang XC, Yang JJ, Wu YL, Zhou Q. Clinical features and intervention timing in patients with pregnancy-associated non-small-cell lung cancer. J Thorac Dis 2021;13(7):4125-4136. doi: 10.21037/jtd-21-234 